\title{
CURRENT STATUS OF SELECTED HEAVY METAL CONTENT IN WATER AND SEDIMENT FROM ASHTAMUDI LAKE, KOLLAM, KERALA, SOUTH INDIA
}

\author{
Lekshmi priya.V and Sherly williams.E \\ Environmental sciences, Aquaculture and Fish Biotechnology unit, \\ Department of Zoology, \\ Fatima Mata National College (Autonomous), Kollam, Kerala, India
}

\begin{abstract}
The study focus on the determination of selected heavy metals such as Cadmium, Chromium, Copper, Lead, and Zinc in water and sediment from three different study sites of Ashtamudi Lake. The areas where industrialization and urbanization prevails are more exposed to heavy metal pollution load. Significant differences between heavy metals concentration of various sites, determined using One- Way analysis of variance (ANOVA) followed by Fisher's LSD post hoc test. Elemental analysis in water was compared with the international standard of WHO and ICMR and those of sediments with USEPA and CCME limits.
\end{abstract}

Key words - Ashtamudi Lake, Heavy metals, ANOVA, Pollution.

\section{INTRODUCTION}

The Ashtamudi lake (61400 ha; $08^{\circ} 57^{\prime} \mathrm{N}$ $\left.076^{\circ} 35^{\prime} \mathrm{E}\right)$, the second largest backwater in kerala has been recognized as one of the toxic hot spots. Due to the flourishing rate of industrialization and urbanization, the scenic beauty of the lake is being exhausted largely. At present scenario, many portions of the lake are dumping yards of untreated sewage from various sources like city waste, intensive coconut husk retting wastes, oil spillage and excreta release from houseboats, effluents from industries and household wastes. The large scale inputs of pollutants from various sources have been drastically altered the water and sediment quality of the lake. Studies on Ashtamudi estuary with special emphasis on its hydrobiology were done by Abdul Azis and Nair (1986), Sujatha et al., (2009) and Babu et al., (2010). They suggested that the water quality of the Lake has been deteriorated at an incredible proportion. Reports on heavy metal contamination in the water and sediment sample of Ashtamudi Lake was documented by Razeena and Sherly (2012),
Geetha Bhadran (1997). With regard to their study reports the mushrooming of industries, tourism activities, discharge of domestic wastes together with encroachment are the predominant factors responsible for deterioration of the Ashtamudi backwaters. As heavy metal constitutes an indispensible part of industrial and domestic effluents, a through monitoring, and studies focusing on heavy metal toxicity is very essential. The main aim of the present study are to assess the pollution load of selected heavy metals such as Cadmium, Chromium, Copper, Lead, and Zinc in water and sediment samples from three different study sites of Ashtamudi Lake.

\section{MATERIALS AND METHODS}

Description of study sites - Kureepuzha, Perumon and West Kallada regions of Ashtamudi Lake were the three targeted study sites. Figure 1 indicates the location map of Ashtamudi lake showing the study sites. Site 1 - Kureepuzha lake is a part of Ashtamudi lake that envelopes the sub island Kureepuzha. The place near the bank of the Kureepuzha region was a dump yard and there is no proper method is available for processing the dumped wastes. Dirty leachate oozes out from the dump yard into the lake especially during rainy seasons, which pollutes the lake. The effluents from Parvathy Mills, Milma Dairy, KSRTC workshop, municipal waste dump site and many small scale industries are the major sources of heavy metals in this region (Razeena et al., 2012). Site 2 Perumon Lake is the part of the Ashtamudi Lake, which spreads between perumon and Pezhumthuruth. Discharge from retting grounds and input of domestic wastes were the major sources of heavy metals in this region (Gireesh Kumar, 2016). A more localized zone of Perumon Lake where the anthropogenic influence over it is higher was choosen as the second study site. 
The Aluminium Industries Ltd., Kerala Ceramics Ltd., Kerala Electrical and Allied/Engineering Company and Technopark are the major industries discharging effluents at this Site. The region nearby this is more trafficking in nature. Site 3 - West
Kallada is the part of the Ashtamudi lake that touches the basin of the Kalladayar. The region of this lake is not much disturbed with anthropogenic interferences and urbanization, is selected as the third and reference site.

Figure 1 : Location map of Ashtamudi Lake.

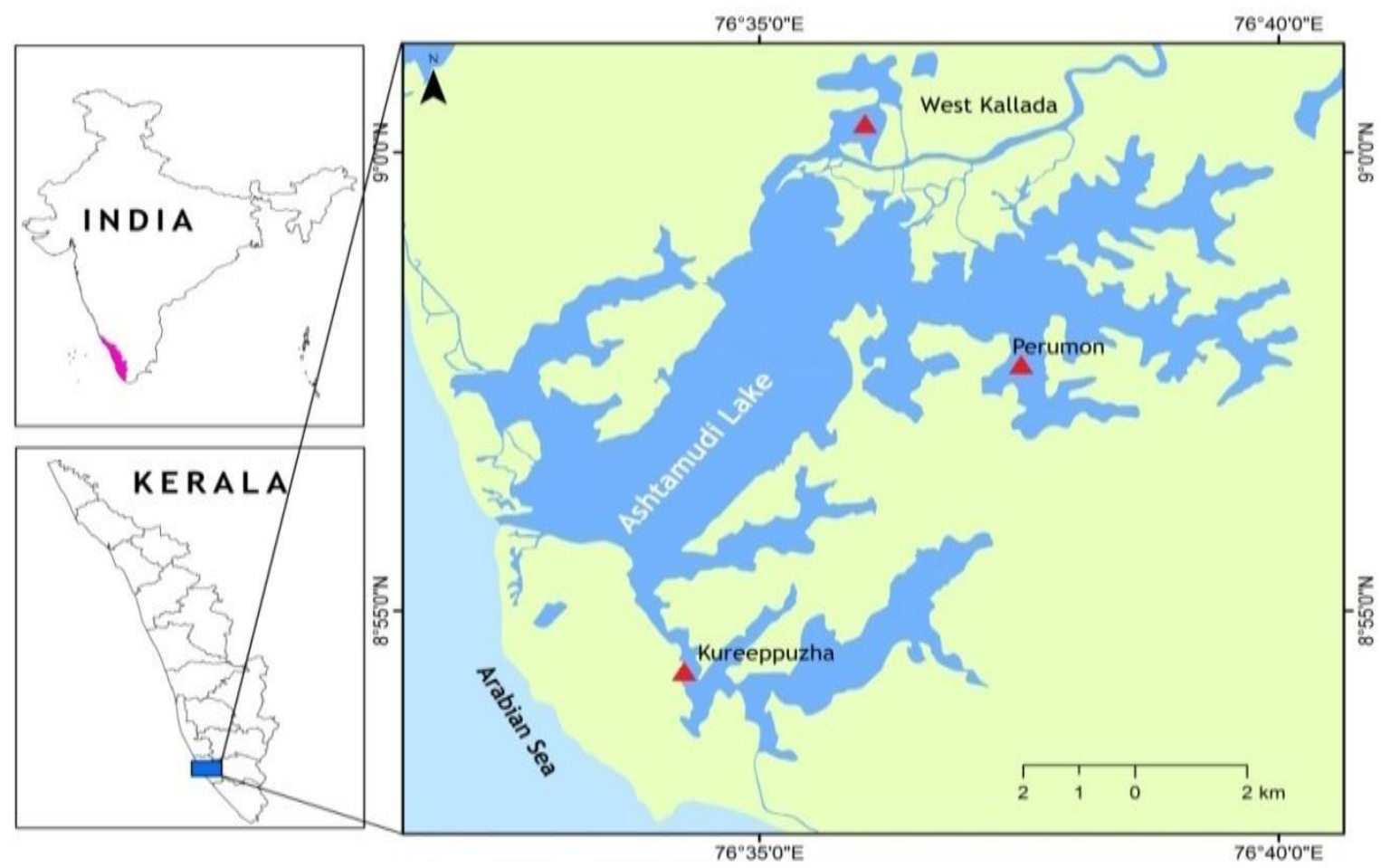

Methodology: Water and sediment samples were collected from the three sites monthly from February 2017 January 2018 for a period of one year. One-liter water samples collected from each site were filtered through Whatmans No.1 filter paper. The samples were preserved with $10 \mathrm{mLs}$ of $6 \mathrm{~N}$ nitric acid and stored at $5^{\circ} \mathrm{C}$. Before elemental analysis, samples were acidified to $\mathrm{pH} 2$ with $20 \mathrm{mLs}$ of $6 \mathrm{~N} \mathrm{HNO3}$. Sediments were collected in separate polythene bags of the study sites. Samples were then digested with nitric acid and hydrofluoric acid in the ratio 5:2 for 30 mins at $200^{\circ} \mathrm{C}$. After cooling the samples, $0.8 \mathrm{~g}$ boric acid was added to dissolve the fluoride precipitates. The heavy metals such as Cadmium, Chromium, Copper, Lead and Zinc in water and sediment samples were determined by atomic absorption spectrophotometer (APHA, 2005 ).

\section{Data generalization and Statistics}

Data obtained was generalized and the results were expressed as mean \pm standard deviation. Statistical analysis of data was performed using SPSS statistical program (Pakage- 22, registered).The data were also plotted on graphs to see their values conveniently. Significant differences between heavy metals concentration of various sites, determined using OneWay analysis of variance (ANOVA) followed by Fisher's LSD post hoc test. The level of significance was $\mathrm{p}<0.05$.

\section{RESULTS AND DISCUSSION}

The results of elemental analysis in water and sediment samples from the selected study sites of Ashtamudi lake was depicted in Table 1 to 6 .

Cadmium is one of the toxic heavy metals, which interferes with metabolic processes of plants and thereby enters to the higher tropic levels of organisms (Adriano, 2001). Electroplating, alloy, metal industry, anthropogenic activities, fossil fuel burning, application of phosphate fertilizers, 


\section{International Journal of Engineering Applied Sciences and Technology, 2019 Vol. 4, Issue 2, ISSN No. 2455-2143, Pages 146-153 \\ Published Online June 2019 in IJEAST (http://www.ijeast.com)}

municipal waste water, sewage sludge, fly-ash , plastics, batteries and leather tanning were considered as the major sources of Cadmium which pollutes the lake (Lone et al., 2008). In the present study cadmium showed highest value at site 1 in both water ( Table 1) and sediment (Table 2). In the case of water, site 1 and 2 was found to be exceeds the WHO (2003) and ICMR (1975) permissible limit and site 3 was below the limit. (Table 4). With respect to sediment, site 1 was above USEPA (2003) and CCME (2009) permissible limit and the other two sites were below the limit below the limit (Table 5). The presence of Cadmium in Site 1 and 2 was mainly due to the influence of anthropogenic activities and other industries which prevails nearby the sites. Considerably higher level of Cadmium at site 1 samples may be due to the discharge of municipal solid wastes and plastics from the nearly situated dump yard of the Lake. Results of ANOVA reveal that no significant variations was observed with respect to Cadmium ( $F=1.741$ ) in the water samples of the three sites (Table 3), whereas in the case of sediment all the three sites was found to be different from their values with respect to the sites ( $\mathrm{F}=13.509$ ) and showed significance of 5\% level ( $\mathrm{p}<0.05)$. Post hoc multiple comparison (LSD) further reveals that all the three sites significantly vary from each other ( Table 5).

The major source of Chromium in natural waters is mainly from electroplating industry, sludge, solid waste, tanneries corrosion inhibitors, varnishes, paints, municipal wastes, manufacture of steel, electric cells, pulp and paperboard mills, petrochemicals, fertilizers Forstner and Wittmann, 1983). Damage to lungs, intestinal tract, the liver, and kidney in aquatic organisms have been reported due to the long-term exposure to chromium. Regarding the Chromium levels in both water (Table 1) and sediment samples, site 1 and site 2 had considerably higher values than site 3 . (Table 2 and Fig 2) In the case of water samples, Site 1 and 2 very closer to the WHO (2003) permissible limit. (Table 4) With respect to sediment, site 1 and 2 was above USEPA (2003) and CCME (2009) limit (Table 6). Site 3 was found to be below the permissible limit of international standards for both water and sediment samples and this may be due to the absence of industrialization and urbanization around the site. Results of ANOVA reveal that significant variations was observed with respect to Chromium in the water $(\mathrm{F}=8.526)$ and sediment $(\mathrm{F}=106.630)$ samples among the three sites (Table 3) and showed significance at 5\% level $(\mathrm{p}<0.05)$. Post hoc multiple comparison (LSD) further reveals that site 1 and 2 significantly vary with site 3 regarding the Chromium levels in water, all the three sites significantly vary among each other in sediment samples ( Table 5).

Copper is an essential elements for living organisms, but it also shows toxicity to aquatic organisms if it exceeds the limit (Jenny and AvenantOldewage.,2006). Mining, electroplating industry, biosolids, smelting and refining etc was regarded as the main sources of the discharge of copper into the aquatic environment (Dara, 1997). In the present study the level of Copper at site 1 water (Table 1, Fig 1) and sediment (Table 2) samples was found to be very higher than other two sites. Site 1 water samples were closer to the permissible limit of WHO (2003) and other two sites were below the limit of WHO (2003) and ICMR (1975) (Table 4). For sediment samples site1 was found to exceeding the limit of CCME (2009) and site 2 and 3 below the CCME (2009) and USEPA (2003) limit. (Table 6). The prevalence of industrialization will further to enhance the chance of crossing the permissible limit of copper especially in site 1 and 2 . Statistical results of ANOVA reveal that significant variations was observed with respect to Copper in the water ( $\mathrm{F}$ $=105.480)$ and sediment ( $\mathrm{F}=63.864)$ samples among the three sites and showed significance at $5 \%$ level $(\mathrm{p}<0.05)$. Post hoc multiple comparison (LSD) further reveals that site 1 significantly varies from other two sites regarding the water samples ( Table 3) and all the three sites significantly vary from each other with respect to sediment samples ( Table 5).

Even when present in lower concentrations Lead produces severe toxicity to aquatic organisms (Rajkumar et al., 2011). The source of the contamination in natural bodies due to lead has been attributed to exhaust of motor vehicles, fly-ash, dredging up harbors, mining and smelting of metalliferous ores, burning of lead gasoline, municipal sewage, industrial wastes enriched in lead, paints, road side soil and dust (Dara, 1997). The results of the present study reveals that in both water and sediment samples the level of Lead is higher in site 1 than site 2 and 3 ( Table 1,2) With reference to the water samples, the value of Lead in site 1 same as that of the limit of WHO (2003) and ICMR (1975) and 2 and 3 was below the limits (Table 4). In case of sediment, all the three sites were found to be below the permissible limit of international standards. (Table 6). Comparatively higher levels of Lead in site 1 are mainly due to the discharge of municipal wastes from the nearby industries. Results of ANOVA reveal that significant variations was observed with 
respect to Lead in the water ( $\mathrm{F}=312.342$ ) and sediment ( $\mathrm{F}=47.632$ ) samples among the three sites and showed significance at $5 \%$ level $(\mathrm{p}<0.05)$. Post hoc multiple comparison (LSD) further reveal that all the three sites significantly vary from each other in both water (Table 3) and sediment (Table 5) samples.

Above certain concentrations and exposure duration Zinc is known to be one of the most toxic metals to many organisms (Maity et al., 2008) . Electroplating industry, smelting and refining, mining, biosolids are mainly responsible to the discharge of Zinc to the natural waters Jamshed and Amit Pal, 2017). With regard to water samples site 2 had higher value than site 1 and 3. (Table 1 and Fig 1) But considering the sediment samples site 1 has considerably greater value than site 2 and 3 (Table 2 ). In both water and sediment samples, all the study sites were safe when compared with the international standard limits (Table 4,6). Results of ANOVA reveal that significant variations was observed with respect to Zinc in the water ( $F=312.342)$ and sediment ( $\mathrm{F}=44.239)$ samples among the three sites and showed significance at $5 \%$ level $(\mathrm{p}<0.05)$. Post hoc multiple comparison (LSD) further reveals that all the three sites significantly vary from each other in water samples (Table 3 ) and site 1 significantly vary with other two sites regarding the sediment samples ( Table 5).

The accumulation order of heavy metals in both water and sediment samples of all the three study sites is $\mathrm{Cu}>\mathrm{Cr}>\mathrm{Pb}>\mathrm{Zn}>\mathrm{Cd}$. According to the study of Razeena Karim and Sherly Williams (2014), among the three study sites of Ashtamudi lake (Kureepuzha, Perumon and Kavanadu) the accumulation order of heavy metals in the water samples of the Perumon region is $\mathrm{Fe}(8.41 \mathrm{mg} / \mathrm{l})>$ $\mathrm{Zn}(0.03 \mathrm{mg} / \mathrm{l})>\mathrm{Cu}(0.02 \mathrm{mg} / \mathrm{l})>\mathrm{Cr}(0.01 \mathrm{mg} / \mathrm{l})>$ $\mathrm{Pb}(0.01 \mathrm{mg} / \mathrm{l})>\mathrm{Cd}(0.003 \mathrm{mg} / \mathrm{l})$ and in the Kureepuzha region the order is $\mathrm{Fe}(9.52 \mathrm{mg} / \mathrm{l})>\mathrm{Zn}$ $(0.10 \mathrm{mg} / \mathrm{l})>\mathrm{Cu}(0.08 \mathrm{mg} / \mathrm{l})>\mathrm{Cr}(0.04 \mathrm{mg} / \mathrm{l})>\mathrm{Pb}($ $0.04 \mathrm{mg} / \mathrm{l})>\mathrm{Cd}(0.005 \mathrm{mg} / \mathrm{l})$. However, these mean values were much lower when compared with the similar sites of the present study. Heavy metal concentration in water from the three sites of Ashtamudi Lake such as Kureepuzha, Perumon and discharge outlet of KSRTC workshop was conducted by KSPCB (Kerala State Pollution Control Board) in 2014. The mean concentration of copper in these sites were $0.06,0.05$ and $0.05 \mathrm{mg} / \mathrm{l}$ and for lead, the values were $0.42,0.25$ and $0.32 \mathrm{mg} / \mathrm{l}$ and for cadmium, the values were $0.09,0.06$ and $0.1 \mathrm{mg} / \mathrm{l}$ and that for manganese, the values were $0.06,0.06$ and $0.08 \mathrm{mg} / \mathrm{l}$ respectively. However these values when compared with the present study sites of Kureepuzha and Perumon reveals that the values were much lower except the mean values of Cadmium at Kureepuzha $(0.035 \mathrm{mg} / \mathrm{l})$ and Perumon $(0.015 \mathrm{mg} / \mathrm{l})$ region. Geetha Bhadran (1997) has also determined heavy metal concentration in water from Arinalloor, Chavara and Kochuthuruthu region of Ashtamudi Lake. The order of heavy metal concentration according to Geetha Bhadran is $\mathrm{Cd}>\mathrm{Pb}>\mathrm{Cu}>\mathrm{Zn}>$ $\mathrm{Fe}$.

Studies on heavy metal concentration on sediments from four different stations of Ashtamudi estuary such as Neendakara, Ashtamudi, Kanjirakode and Kadapuzha were done by Abdul Azis and Nair (1986). Among the six heavy metals studied Ashtamudi showed the highest concentration of $\mathrm{Ni}$ $(18 \mu \mathrm{g} / \mathrm{g}), \mathrm{Cu}(154 \mu \mathrm{g} / \mathrm{g})$ and $\mathrm{Fe}(3900 \mu \mathrm{g} / \mathrm{g})$ than the other stations. Neendakara showed the highest concentration of $\mathrm{Hg}(0.037 \mu \mathrm{g} / \mathrm{g})$ and Kanjirakode showed highest concentration of $\mathrm{Zn}(115.2 \mu \mathrm{g} / \mathrm{g})$. The concentration of Lead was comparatively higher $(0.92 \mu \mathrm{g} / \mathrm{g})$ in Kadapuzha and Neendakara than the other stations. In another study on heavy metal distribution of sediments from 52 stations of Ashtamudi estuary by Nair and Abdul Azis it was reported that the $\mathrm{Pb}$ concentration ranged from 36.4 to $40.8 \mu \mathrm{g} / \mathrm{g}, \mathrm{Zn}$ from 45 to $109.7 \mu \mathrm{g} / \mathrm{g}$, Ni from 10.2 to $14.5 \mu \mathrm{g} / \mathrm{g}, \mathrm{Cu}$ from 20 to $145 \mu \mathrm{g} / \mathrm{g}$, Fe from 800 to $2500 \mu \mathrm{g} / \mathrm{g}$ and $\mathrm{Hg}$ from 0.001 to $0.020 \mu \mathrm{g} / \mathrm{g}$. The higher concentration of heavy metals in water and sediment samples according to the above-mentioned authors was due to the discharge of oil spills from mechanized boats and trawlers, automobile discharges and dumping of untreated wastes from industrial sources and intensive fishing operations prevailing in these areas. The present study also agrees with the previous study reports that the main source of heavy metal contamination at site 1 and site 2 region of Ashtamudi lake is predominantly due to the discharge of effluents from nearby sources.

Table 1: The monthly variation of heavy metals in the water samples from the study sites of Ashtamudi lake (mg/L).

\begin{tabular}{|c|c|c|c|c|c|c|c|c|c|c|c|c|c|c|c|}
\hline \multirow[t]{2}{*}{ Months } & \multicolumn{3}{|c|}{$\underset{(\mathrm{mg} / \mathrm{L})}{\text { Cadmium }}$} & \multicolumn{3}{|c|}{$\begin{array}{c}\text { Chromium } \\
(\mathrm{mg} / \mathrm{L})\end{array}$} & \multicolumn{3}{|c|}{$\begin{array}{c}\text { Copper } \\
(\mathrm{mg} / \mathrm{L})\end{array}$} & \multicolumn{3}{|c|}{$\begin{array}{c}\text { Lead } \\
(\mathrm{mg} / \mathrm{L})\end{array}$} & \multicolumn{3}{|c|}{$\begin{array}{c}\text { Zinc } \\
(\mathrm{mg} / \mathrm{L})\end{array}$} \\
\hline & $\begin{array}{l}\text { Site } \\
1\end{array}$ & $\begin{array}{l}\text { Site } \\
2\end{array}$ & $\begin{array}{l}\text { Site } \\
\mathbf{3}\end{array}$ & Site1 & Site2 & Site3 & Site1 & Site2 & Site3 & Site1 & Site2 & Site3 & Site 1 & Site2 & Site3 \\
\hline
\end{tabular}


International Journal of Engineering Applied Sciences and Technology, 2019

Vol. 4, Issue 2, ISSN No. 2455-2143, Pages 146-153

Published Online June 2019 in IJEAST (http://www.ijeast.com)

\begin{tabular}{|c|c|c|c|c|c|c|c|c|c|c|c|c|c|c|c|}
\hline February & 0.003 & 0.002 & BDL & 0.065 & 0.054 & 0.02 & 0.751 & 0.03 & 0.44 & 0.051 & 0.079 & BDL & 0.01 & 0.5 & 0.009 \\
\hline March & 0.005 & 0.004 & BDL & 0.071 & 0.035 & 0.035 & 0.894 & 0.02 & 0.42 & 0.088 & 0.006 & 0.04 & 0.009 & 0.498 & 0.007 \\
\hline April & 0.006 & 0.005 & BDL & 0.055 & 0.049 & 0.041 & 0.66 & 0.02 & 0.038 & 0.062 & 0.008 & BDL & 0.019 & 0.521 & 0.008 \\
\hline May & 0.005 & 0.007 & BDL & 0.088 & 0.064 & 0.04 & 0.799 & 0.04 & 0.025 & 0.054 & 0.014 & BDL & 0.018 & 0.598 & 0.006 \\
\hline June & 0.009 & 0.003 & BDL & 0.13 & 0.045 & BDL & 0.95 & 0.05 & 0.022 & 0.041 & 0.029 & BDL & 0.14 & 0.65 & 0.009 \\
\hline July & 0.24 & 0.124 & BDL & 0.1 & 0.11 & $\mathrm{BDL}$ & 0.791 & 0.039 & 0.01 & 0.062 & 0.024 & BDL & 0.139 & 0.69 & 0.01 \\
\hline August & 0.12 & 0.009 & BDL & 0.09 & 0.098 & BDL & 0.81 & 0.035 & 0.012 & 0.072 & 0.06 & 0.03 & 0.17 & 0.599 & 0.02 \\
\hline Septembr & 0.008 & 0.007 & 0.002 & 0.091 & 0.054 & BDL & 0.79 & 0.049 & 0.025 & 0.051 & 0.019 & BDL & 0.16 & 0.689 & 0.029 \\
\hline October & 0.006 & 0.005 & BDL & 0.12 & 0.39 & BDL & 0.698 & 0.029 & 0.028 & 0.017 & 0.009 & BDL & 0.16 & 0.579 & 0.041 \\
\hline Novembr & 0.009 & 0.008 & $\mathrm{BDL}$ & 0.1 & 0.09 & BDL & 0.399 & 0.045 & 0.035 & 0.029 & 0.008 & BDL & 0.19 & 0.574 & 0.034 \\
\hline December & 0.005 & 0.005 & BDL & 0.11 & 0.1 & BDL & 0.48 & 0.041 & 0.048 & 0.021 & 0.006 & BDL & 0.179 & 0.56 & 0.039 \\
\hline January & 0.007 & 0.003 & BDL & 0.08 & 0.088 & BDL & 0.67 & 0.03 & 0.047 & 0.044 & 0.005 & BDL & 0.196 & 0.54 & 0.01 \\
\hline
\end{tabular}

$*$ BDL in the tabular column indicates below detection limit of the instrument (ie, < 0.05 ).

Table 2: The monthly variation of heavy metals in the Sediment samples from the study sites of Ashtamudi lake (mg/kg).

\begin{tabular}{|c|c|c|c|c|c|c|c|c|c|c|c|c|c|c|c|}
\hline \multirow[t]{2}{*}{ Months } & \multicolumn{3}{|c|}{$\begin{array}{c}\text { Cadmium } \\
(\mathrm{mg} / \mathrm{kg})\end{array}$} & \multicolumn{3}{|c|}{$\begin{array}{c}\text { Chromium } \\
(\mathrm{mg} / \mathrm{kg})\end{array}$} & \multicolumn{3}{|c|}{$\begin{array}{l}\text { Copper } \\
\text { (mg/kg) }\end{array}$} & \multicolumn{3}{|c|}{$\begin{array}{c}\text { Lead } \\
(\mathrm{mg} / \mathrm{kg})\end{array}$} & \multicolumn{3}{|c|}{$\begin{array}{c}\text { Zinc } \\
(\mathrm{mg} / \mathrm{kg})\end{array}$} \\
\hline & $\begin{array}{l}\text { Site } \\
1\end{array}$ & $\begin{array}{l}\text { Site } \\
2\end{array}$ & $\begin{array}{l}\text { Site } \\
3\end{array}$ & Site1 & Site2 & Site3 & Site1 & Site2 & Site3 & Site1 & Site2 & Site3 & Site 1 & Site2 & Site3 \\
\hline February & 0.52 & 0.46 & BDL & 38.45 & 29.81 & 0.99 & 11.48 & 7.49 & 1.34 & 20.39 & 2.19 & 0.95 & 58 & 37.12 & 14.99 \\
\hline March & 1.72 & 0.62 & 0.29 & 41 & 35.91 & 1.91 & 9.48 & 8.45 & 2.37 & 24.34 & 2.17 & 1 & 78 & 29.13 & 14.82 \\
\hline April & 0.57 & 0.59 & BDL & 28.41 & 38.08 & 1.68 & 13.61 & 7.45 & 2.21 & 39.71 & 3.18 & 1.21 & 49.91 & 24.13 & 14.98 \\
\hline May & 0.63 & 0.63 & BDL & 49.62 & 29.95 & 0.45 & 16.51 & 12.41 & 1.38 & 18.71 & 2.98 & 0.91 & 60 & 31.51 & 6.74 \\
\hline June & 0.44 & 0.53 & BDL & 59.62 & 41.12 & 0.61 & 17.48 & 15.42 & 4.26 & 16.21 & 2.27 & 0.54 & 98.22 & 41.21 & 17.12 \\
\hline July & 2.94 & 0.43 & BDL & 72.32 & 52.9 & 0.55 & 16 & 14.41 & 2.13 & 46.34 & 4.25 & 0.64 & 90 & 45.32 & 16.12 \\
\hline August & 0.55 & 0.61 & BDL & 43.91 & 40 & 0.69 & 23.6 & 12.31 & 3.14 & 29.62 & 6.26 & 0.56 & 127 & 47 & 15.5 \\
\hline September & 1.29 & 0.34 & BDL & 41 & 31.88 & 0.65 & 20.87 & 10.59 & 5.12 & 12.71 & 2.98 & 0.54 & $\begin{array}{c}158.2 \\
1\end{array}$ & 39.32 & 13.98 \\
\hline October & 0.55 & 0.32 & $\mathrm{BDL}$ & 61.91 & 51.98 & 0.42 & 19.63 & 8.41 & 4.14 & 19.01 & 2.21 & 0.51 & $\begin{array}{c}144.5 \\
2 \\
\end{array}$ & 19.2 & 13.91 \\
\hline November & 1.44 & 0.31 & BDL & 39.92 & 41.22 & 0.41 & 14.61 & 9.32 & 3.15 & 12.92 & 3.19 & 0.52 & 94 & 21.21 & 14.51 \\
\hline December & 0.46 & 0.14 & BDL & 41 & 49.82 & 0.64 & 13.51 & 10.61 & 2.16 & 17.13 & 1.18 & 0.49 & 84 & 30.05 & 14.6 \\
\hline January & 0.61 & 0.12 & BDL & 52 & 41.52 & 0.89 & 21.62 & 12.41 & 2.15 & 13.91 & 2.18 & 0.521 & 72.38 & 27 & 15.24 \\
\hline
\end{tabular}

$*$ BDL in the tabular column indicates below detection limit of the instrument (ie, $<0.05$ )

Table 3: Analysis of variance (One-Way ANOVA) of heavy metals of the water samples of the Ashtamudi Lake.

\begin{tabular}{|c|c|c|c|c|c|}
\hline & \multicolumn{2}{|c|}{ Study sites } & & \\
\hline Heavy metals & $\begin{array}{c}\text { Site 1 } \\
\text { Mean } \pm \text { SD) }\end{array}$ & $\begin{array}{c}\text { Site 2 } \\
\text { (Mean } \pm \text { SD) }\end{array}$ & $\begin{array}{c}\text { Site 3 } \\
\text { (Mean } \pm \text { SD) }\end{array}$ & $\begin{array}{c}\text { F value comparing } \\
\text { study sites }\end{array}$ & P Value \\
\hline Cadmium & $0.035 \pm .072$ & $0.015 \pm 0.034$ & $0.000 \pm 0.000$ & 1.741 & NS \\
\hline Chromium & $0.091 \pm 0.022^{\mathbf{a}}$ & $0.098 \pm 0.095^{\mathbf{a}}$ & $0.011 \pm 0.017^{\mathbf{b}}$ & 8.526 & $<\mathbf{0 . 0 5}^{*}$ \\
\hline Copper & $0.724 \pm 0.158^{\mathbf{a}}$ & $0.035 \pm 0.010^{\mathbf{b}}$ & $0.095 \pm 0.156^{\mathbf{b}}$ & 105.480 & $<\mathbf{0 . 0 5}^{*}$ \\
\hline Lead & $0.05 \pm 0.020^{\mathbf{a}}$ & $0.022 \pm 0.023^{\mathbf{b}}$ & $0.005 \pm 0.013^{\mathbf{c}}$ & 14.712 & $<\mathbf{0 . 0 5}^{*}$ \\
\hline Zinc & $0.115 \pm 0.077^{\mathbf{a}}$ & $0.583 \pm 0.066^{\mathbf{b}}$ & $0.018 \pm 0.013^{\mathbf{c}}$ & 312.342 & $<\mathbf{0 . 0 5}^{*}$ \\
\hline
\end{tabular}

$*=\mathrm{p}<0.05$, The mean difference is significant at $5 \%$ level; SD - Standard deviation; NS - Not significant ;

a, b,c - Means within rows with differing subscripts are significantly different using Fisher's LSD post hoc test

Table 4: Comparing the elemental analysis in the water samples with international standards

\begin{tabular}{|c|c|c|c|c|}
\hline Heavy metals & $\begin{array}{c}\text { WHO limits } \\
(\mathrm{mg} / \mathrm{l})\end{array}$ & $\begin{array}{c}\text { ICMR limits } \\
(\mathrm{mg} / \mathrm{l})\end{array}$ & $\begin{array}{c}\text { Present study }- \\
\text { mean values }(\mathrm{mg} / \mathrm{kg})\end{array}$ & Inference \\
\hline
\end{tabular}


International Journal of Engineering Applied Sciences and Technology, 2019

Vol. 4, Issue 2, ISSN No. 2455-2143, Pages 146-153

Published Online June 2019 in IJEAST (http://www.ijeast.com)

\begin{tabular}{|c|c|c|c|c|c|c|}
\hline & & & Site1 & Site 2 & Site3 & \\
\hline Cadmium & 0.005 & 0.01 & 0.035 & 0.015 & 0.000 & $\begin{array}{c}\text { Site } 1 \text { and 2 above WHO and } \\
\text { ICMR permissible limit and } \\
\text { site 3 below the limit }\end{array}$ \\
\hline Chromium & 0.1 & - & 0.091 & 0.098 & 0.011 & $\begin{array}{c}\text { Site } 1 \text { and } 2 \text { very closer to the } \\
\text { WHO permissible limit and } \\
\text { site } 3 \text { below the limit }\end{array}$ \\
\hline Copper & 1.0 & 1.5 & 0.724 & 0.098 & $\begin{array}{c}\text { Site 1 closer to the permissible } \\
\text { limit of WHO and two sites } \\
\text { below the limit of WHO and } \\
\text { ICMR }\end{array}$ \\
\hline Lead & 0.05 & 0.05 & 0.05 & 0.022 & 0.005 & $\begin{array}{l}\text { Site 1 same as that of the limits } \\
\text { of WHO and ICMR and 2 and } \\
3 \text { below the limits }\end{array}$ \\
\hline Zinc & 5.0 & 0.10 & 0.049 & 0.022 & 0.005 & $\begin{array}{c}\text { All sites below permissible } \\
\text { limits }\end{array}$ \\
\hline
\end{tabular}

Table 5: Analysis of variance (One-Way ANOVA) of heavy metals of the sediment samples of the Ashtamudi Lake.

\begin{tabular}{|c|c|c|c|c|c|}
\hline & \multicolumn{3}{|c|}{ Study sites } & \multirow[b]{2}{*}{$\begin{array}{c}\text { F value comparing } \\
\text { study sites }\end{array}$} & \multirow[b]{2}{*}{ P Value } \\
\hline Heavy metals & $\begin{array}{c}\text { Site } 1 \\
(\text { Mean } \pm \text { SD })\end{array}$ & $\begin{array}{c}\text { Site } 2 \\
(\text { Mean } \pm \text { SD })\end{array}$ & $\begin{array}{c}\text { Site } 3 \\
(\text { Mean } \pm \text { SD })\end{array}$ & & \\
\hline Cadmium & $0.976 \pm 0.754^{\mathrm{a}}$ & $0.425 \pm 0.180^{b}$ & $0.0242 \pm 0.083^{\mathrm{c}}$ & 13.509 & $<0.05 *$ \\
\hline Chromium & $47.430 \pm 12.20^{\mathrm{a}}$ & $40.349 \pm 7.983^{b}$ & $0.824 \pm 0.488^{\mathrm{c}}$ & 106.630 & $<0.05^{*}$ \\
\hline Copper & $16.533 \pm 4.285^{\mathrm{a}}$ & $10.773 \pm 2.654^{b}$ & $2.795 \pm 1.187^{\mathrm{c}}$ & 63.864 & $<0.05^{*}$ \\
\hline Lead & $22.583 \pm 10.784^{\mathrm{a}}$ & $2.920 \pm 1.302^{\mathrm{b}}$ & $0.699 \pm 0.247^{\mathrm{b}}$ & 44.239 & $<0.05 *$ \\
\hline Zinc & $92.853 \pm 34.37^{\mathrm{a}}$ & $32.683 \pm 9.248^{b}$ & $14.375 \pm 2.563^{c}$ & 47.632 & $<0.05^{*}$ \\
\hline
\end{tabular}

$*=\mathrm{p}<0.05$, The mean difference is significant at 5\% level; SD - Standard deviation; ${ }^{\mathrm{a}, \mathrm{b}, \mathrm{c}}$ - Means within rows with differing subscripts are significantly different using Fisher's LSD post hoc test

Table 6: Comparing the elemental analysis in the sediment samples with international standards

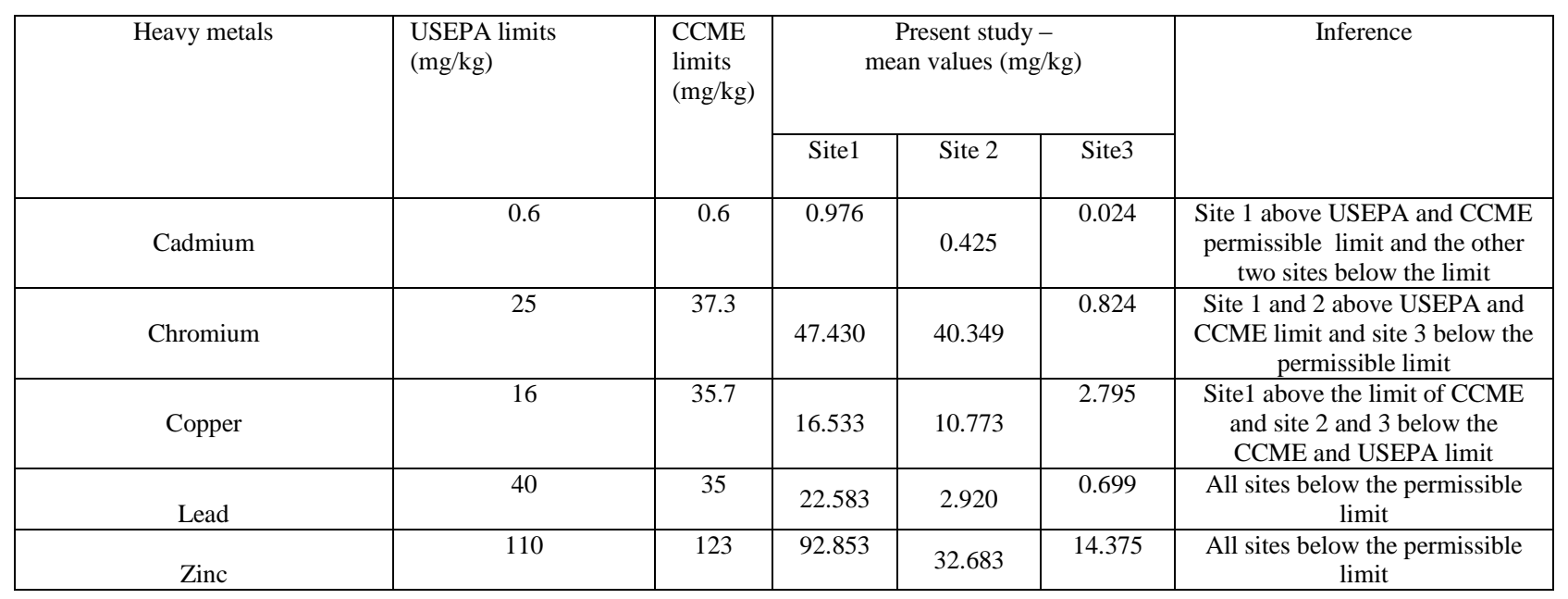

\section{CONCLUSION}

With regards for the selected heavy metal study in water and sediment of Ashtamudi Lake, site
1 and 2 seems to be more contaminated with heavy metal pollution. Considerably lower levels of heavy metals were found in the site 3 samples. More over all the selected heavy metals for the present study in 
site 3 samples were also found to be below the permissible limits in accordance with the international standards. This is because of the absence of industralisation and urbanization around the site 3 and hence this region of Ashtamudi Lake can be considered as a reference site when compared with the other two sites. The higher levels of heavy metals in site 1 and site 2 are especially due to industrialization and urbanization surrounding the lake. Significantly, higher concentrations of heavy metals have been observed in the present study samples when compared with the previous study reports. This is mainly due to the blooming of industrialization and urbanization day by day. Flourishment of industrialization and urbanization around the Lake will further enhance the discharge of toxic heavy metals into the water body. If immediate care and attention is not provided to the protection of the lake, metals such as Copper and Zinc too will cross the standard permissible limits in near future. A through monitoring and examination of the lake is very essential for the sake of protection of the lake.

\section{ACKNOWLEDGEMENT}

The authors are grateful to Kerala University, Thiruvananthapuram for the financial assistance and the management of Fatima Mata National College for providing the facilities.

\section{REFERENCES}

1. Abdul Azis P.K., and Nair N.B. (1986). Ecology of the coconut husk retting grounds in Kerala. Proceedings of the symposium on costal Aquaculture.Culture of the Orgamnisms, environmental studies, Training Extension and Legal Aspects, (pp.1115-1130).

2. Sujatha C.H.; Nify B.; Ranjitha R.; Fanimol C.L. and Samantha, N. K. (2009). Nutrient dynamics in the two lakes of Kerala, India. Indian Journal of Marine Sciences, (pp.451456).

3. Babu, K.N. ; Omana, P.K., and Mohan, M. (2010). Water and sediment quality of Ashtamudi estuary, a Ramsar site, southwest coast of India-a statistical appraisal. Environmental Monitoring and Assessment, (pp.307-319).

4. Razeena, K.L. ; and Sherly, W. E. (2014). Bioaccumulation of heavy metals in an estuarine fish Liza parsia of Ashtamudi Lake-Southwest coast of Kerala, India. The
International Journal of Science and Technology, (pp 169 - 171).

5. Geetha Bhadran. (1997) Heavy metal pollution in Ashtamudi estuarine system. Ph.D. Thesis, University of Kerala.

6. Razeena, K.L. ; Sherly, W.E. and Vishnu,N.M.S., (2012). Muncipal solid waste dumping on Ashtamudi lake, Kollam, Kerala - an overview. The Ecoscan, (pp 105110).

7. Girish Kumar, B. (2016). Toxicity induced changes of $\mathrm{Cu}$ and $\mathrm{Pb}$ on the humoral and cellular factors on Anabas testudineus (Bloch, 1792) Ph.D. thesis, Cochin University of Science and Technology.

8. APHA. (2005). Standard Methods for Examination of Water and Wastewater Association/Water Environment Federation, Washington D.C., USA.

9. Adriano,D.C. (2001). Trace elements in terrestrial environments:Biochemistry, bioavailability and risks of metals. Springer Verlag.

10. Lone, M.I.H.E. ; Zhen-li Peter, J.S, ; Yang,X (2008). Phyto remediation of heavy metal polluted soils and water Progresses and perspectives.J. Zhejiang University, (pp. 210-220).

11. WHO., (2003). Guidelines for Drinking Water Quality. World Health Organization, Geneva, (pp.249).

12. I.C.M.R., (1975). Manuals of standards of quality for drinking water supplies. I.C.M.R. New Delhi.India,

13. U.S.EPA., (Environmental Protection AgencyGuidance for the development of ecological soil screening levels) (2003) Office of Solid Waste and Emergency Response, Washington, DC.

14. Canadian Council of Ministers of the Environment (CCME). (2009) Update. Canadian environmental quality guidelines. Canadian Council of Ministers of the Environment, Winnipeg, Manitoba.

15. Forstner J., and Wittmann G.T.W. (1983). Metal pollution in the aquatic environment. Springer-Verlag, Berlin.

16. Jenny R., and Avenant-Oldewage A. (2006). Chromium, Copper, Iron and Manganese bioaccumulation in some organs and tissues of Oreochromis mossambicus from the lower Olifants River, inside the Kruger National Park, (pp 387).

17. Dara S.S ., (1997). A text book of environmental chemistry and pollution 
control S. Chand \& Company Ltd., New Delhi, (pp. 1-242).

18. Rajkumar, J.S.I., John Milton, M.C., Ulthiralingam,M., Azhaguraj, R., Ganesh, J., and Ambrose. T. (2011). Toxic effects and bioaccumulation of cadmium, copper, lead and zinc in post larval stages of Penaeus monodon. International Journal of Development Research, (PP. 1-5).
19. Maity, S., Roy,S., Chaudhury, S., and Bhattacharya, S. (2008). Antioxidant responses of the earthworm Lampito mauritii exposed to $\mathrm{Pb}$ and $\mathrm{Zn}$ contaminated soil. Environmental Pollution, (PP.1-7).

20. Jamshed, Z., and Amit Pal (2017). Review on heavy metal pollution in major lakes of India:Remediation through plants. African Journal of Environmental Science and Technology, ( pp. 255-265). 